September -2009

\title{
Harnessing Open Educational Resources to the Challenges of Teacher Education in Sub-Saharan Africa
}

\author{
Jayshree Thakrar and Denise Zinn \\ University of Fort Hare, South Africa \\ Freda Wolfenden \\ Open University, UK
}

\begin{abstract}
The challenges to teacher educators in sub-Saharan Africa are acute. This paper describes how the Teacher Education in Sub-Saharan Africa (TESSA) consortium is working within institutional and national policy systems to support school-based teacher professional development. The TESSA consortium (13 African institutions and 5 international organisations delivering teacher education across 9 countries) designed and produced a bank of open educational resources (OERs) to guide teachers' classroom practices in school-based teacher education. Drawing on examples from the TESSA consortium and from the University of Fort Hare, South Africa, the authors categorize the forms of TESSA OER integration as highly structured, loosely structured, or guided use. The paper concludes by outlining success factors for the integration of OERs: accessibility, adequate resources, support for teachers, accommodation of local cultural and institutional practices, and sustainable funding.
\end{abstract}

Keywords: Open educational resources; sub-Saharan Africa; teacher education; school-based teacher development; TESSA

\section{Teacher Education and Open Educational Resources}

Teacher education now lies at the heart of all development schemes. It has already been recognized as one of the major areas of focus for poverty reduction, economic progress and social and cultural development. Development initiatives...affirm the critical importance of education and the role played by teachers. (Teferra \& Skauge, n.d., p. 3) 
Education is critical to many development initiatives. But, at the same time, there is widespread recognition that there are enormous global challenges facing the education sector. Foremost amongst these is the severe shortage of teachers in countries where they are most needed; to meet the challenges of the Education for All (EFA) goals, somewhere between 15 and 35 million new teachers are required globally by 2015 (UNESCO, 2007). In Africa, south of the Sahara alone, it is estimated that approximately 4 million additional teachers will be needed to fill both new posts and vacancies (to deliver a complete course of primary schooling for all children); this need is due to attrition caused in particular by the effects of HIV/AIDs and the migration of trained teachers into other sectors of the economy and other countries outside of the region (UNESCO, 2008).

The challenge is to ensure a well-prepared, engaged, and committed corps of teachers in sufficient numbers, whilst working within budgetary and infrastructure constraints. In developing countries this challenge is amplified by the significant numbers of un- and under-qualified teachers; these teachers urgently need access to professional development opportunities. Across sub-Saharan Africa the minimum level of qualification required for teachers varies, but these standards are generally lower in sub-Saharan Africa than in other regions. Even so only four countries report all teachers meeting their requirements (UNESCO, 2006). In the Congo and Mozambique less than two-thirds of teachers meet the minimum international standard of lower secondary education. This lack of training impacts on pupil achievement; in developing countries evidence is emerging that the strongest school-level determinant of pupil achievement lies in the quality of teaching (Adekola, 2007; Schwille et al., 2007).

Despite the urgency created by these challenges, Kirk and Dembélé (2007, p. 1) caution that, "Short-term responses to teacher shortages can ensure that every classroom has a teacher, but raises concerns about the impact on the quality of teaching and learning." Quality has to be a fundamental criterion, but responses to these challenges also need to take into consideration contextual and environmental factors, in particular the lived reality for many teachers.

However, as Weber argues (2007, p. 293), "The job of teaching in poor countries is defined by the struggle to cope in the absence of basic resources and the consequences of structural adjustment programmes." Chronic underfunding, corruption, and instability related to frequent political and policy changes contribute to difficult working conditions in many areas of subSaharan Africa. Teacher motivation, aspiration, and morale are important contextual factors, and it has to be borne in mind that "(many) teachers in conflict-affected, emergency or post-crisis situations may not originally have intended to enter the profession, but did so to respond to the needs of their communities or to the lack of other livelihood opportunities" (Kirk \& Dembélé, 2007, p. 2).

Given these kinds of realities, how best can effective teacher training that promotes quality education be delivered? Teacher training colleges and institutions have limited capacity to expand, and there is an imperative to retain existing teachers in classrooms with their pupils whilst they engage in professional development. As well, it is important to focus on what actually happens in teachers' own classrooms rather than on guides, suggestions, and theories of what 
should happen in classrooms (Schwille et al., 2007). This requires teachers who are empowered to think about their work with their peers and to both provide and get feedback on what they do. In Japan and China, these ideas have found successful 'take-up' through the establishment of jugyokenkyu (lesson study) and jiaoyanzu (teacher research) (Schwille, 2007).

Such works, and several recent reports, make the case for urgent new thinking about the forms and structure of teacher education (UNESCO, 2007; UNESCO, 2008). At the re-launch of the Partnership for Higher Education in Africa (September, 2005), Dr Kofi Annan made the following appeal: "We need to train teachers and build up research capacity; we need to strengthen open universities and distance learning programmes; and we need to ensure that African institutions have access to the latest technologies" (2005, October 3).

Across the globe there is increasing interest in different forms of school-based modes of teacher education and in using the tools offered by new information and communication technologies (ICT), including open educational resources (OERs), for large-scale provision (Moon, 2007). These initiatives not only increase capacity for teaching training systems but also offer opportunities to enhance the articulation between theory and practice and to support teachers more effectively in becoming reflective practitioners. Recent reports from the sub-Saharan African region indicate some ambitious experimentation but, as yet, few initiatives utilizing educational technologies within the training process itself (Farrell et al., 2007).

School-based teacher development programmes demand resources and reference materials to guide and grow teachers' classroom practices; these are frequently scarce in sub-Saharan Africa. But the recent advent of open content or open educational resources (OERs), a global intellectual resource of teaching materials, offers a significant breakthrough. This paper describes how the Teacher Education in Sub-Saharan Africa (TESSA) consortium is working collaboratively within institutional and national policy systems to develop and use OERs to support innovative schoolbased professional development (Wolfenden, 2008). We reflect on the range of approaches to the use of OERS observed in the consortium to date and suggest key areas for further exploration in the use of OERs.

\section{TESSA (Teacher Education in Sub-Saharan Africa)}

TESSA is a research and development project working to improve the quality of, and extend access to, university-led primary school teacher education. Since its inception in 2005 the TESSA consortium of 18 institutions has worked collaboratively to design and build a multi-lingual OER bank, modular and flexible in format (see www.tessafrica.net); core funding for TESSA is from the Allan and Nesta Ferguson Charitable Trust and the William and Flora Hewlett Foundation, with both donors providing follow-up grants. At the heart of the TESSA OER bank are sets of practically focused study units designed to directly improve teacher classroom practice; each of the 75 study units contains a series of activities for teachers to carry out with their pupils. These activities centre on clearly defined strategies for teachers to think about and experiment with in their classrooms. Guidance for teacher educators is provided, demonstrating how study units link together, and student progression is supported through each module (collection of 5 study units). 
Each study unit has been adapted and versioned to the nine country contexts of participating TESSA institutions, including translation to Arabic, English, French, and Kiswahili. The design of the TESSA web environment is organized to enable each country/institution to have their own web presence, and because of the current challenges in connectivity and access the study units are provided in a range of formats. The template for the TESSA study units together with the design, versioning, and development processes are fully explained in earlier descriptions of our work (Wolfenden, 2008).

\section{Integrating TESSA OERs}

The first phase of TESSA focused on design and production of the study units and web space, but considerable resource was also devoted to planning for the use of the study units in each of the 13 partner institutions delivering teacher education in the region. Consortium institutions are engaged in delivery and accreditation of a large number of different types of courses and programmes, pre-service, in-service, on-campus, distance learning, certificate, diploma, and B.Ed., together with non-accredited short professional development courses.

There has been no blueprint for integration of the TESSA OERs into this vast range of programmes and courses; rather, implementation is a dispersed and decentralized process. The TESSA framework takes account of the knowledge and problem-solving abilities that exist within each partner institution (Elmore, 2000). Within the professionally supportive structure of the consortium, each institution is given the freedom to decide on the programme(s) or courses, selection of TESSA OERs, mode of access of OERs, and so on to best meet local needs and context.

TESSA coordinators at each partner institution, who occupy a variety of institutional roles, are important to the change process. Their knowledge of the social structures within which they are operating, the competing agendas, and the relative influence of different layers within their institutions are crucial in understanding the potential effects of the chosen implementation strategy for the TESSA OERs. The delegated discretion accorded to TESSA coordinators in each TESSA partner institution enables them to develop the most direct path for greatest impact on teachers' practices in their context. They provide the connection between the pedagogic frameworks of the TESSA resources and approach and the detail of practice in schools (Elmore, 2000a).

\section{Forms of Integration}

Through 2009 over 200,000 teachers are planned to engage with the TESSA OERs across nine countries: Ghana, Kenya, Nigeria, Rwanda, South Africa, Sudan, Tanzania, Uganda, and Zambia. Analysis to date of the form and mode of use of the TESSA OERs in partner institutions suggest that these can be grouped as the following: highly structured, loosely structured, and guided use. 
The highly structured model is characterized by production of a 'guide' or course book of activities or whole study units drawn directly from the TESSA Resource Bank - a learning journey with TESSA materials. In some cases these TESSA materials are interspersed with other activities, narratives, and exercises. Teacher engagement with issues of particular relevance has been strengthened by the addition of commentaries and prompts for the teacher to consider as they think about enactment in their own classrooms. These books or guides have generally been designed by senior academics for use on distance education courses, where teachers are supported by tutors or supervisors.

Key proponents of this model in the TESSA consortium have been the National Teachers' Institute (Nigeria) and the Open University of Sudan. Both institutions operate distance education at large-scale; many of their students will be located in rural areas with little chance of access to the Internet or regular support from institution staff. However distribution channels for hard copy materials are well established. At the Open University of Sudan, academics have undertaken a comprehensive mapping exercise with the TESSA materials (in Arabic) against both the teachertraining curriculum and the school pupil curriculum to pull together a book of TESSA study units. This book will be used by all students in the third and final teaching practice of their bachelor's programme. This year, the cohort numbers 53,000. In Sudan, as in many countries across the world, the pupil curriculum is highly controlled and fixed, but by careful linking of the TESSA activities with the school curriculum, TESSA materials can be used "without alienating head teachers" (Sineda, 2009). The National Commission for Colleges of Education in Nigeria (a federal government body) has created similar books based on TESSA materials, one for each area of the primary curriculum. Each book links 10 classroom activities (drawn from TESSA study units) alongside questions to prompt teacher experimentation and reflection. These books are to be used with all pre-service teachers across Nigeria. In both instances there were previously no resources to support the student teachers' whilst on teaching practice and the books provide a structure and framework for skills development.

In what we have termed the loosely structured model, lecturers in partner institutions have selected TESSA study units to use in their own courses. This selection, usually at workshops, has involved matching the learning outcomes (typically highly subject knowledge specific) of selected existing modules to the curriculum focus of the TESSA materials. The following table shows an example from a workshop with lecturers at Egerton University in Kenya (October, 2008). 
Table 1

Loosely Structured Model: Example from Egerton University Workshop

\begin{tabular}{|c|c|c|c|c|}
\hline $\begin{array}{l}\text { B. Ed } \\
\text { (Primary) }\end{array}$ & $\begin{array}{l}\text { Theme } \\
\text { topic }\end{array}$ & $\begin{array}{l}\text { Suggested } \\
\text { TESSA } \\
\text { module / } \\
\text { section }\end{array}$ & $\begin{array}{l}\text { Suggested TESSA } \\
\text { activities }\end{array}$ & $\begin{array}{l}\text { Teacher learner } \\
\text { outcomes }\end{array}$ \\
\hline $\begin{array}{l}\text { PECI } 111 \\
\text { Introduction } \\
\text { to Basic } \\
\text { Mathematics } \\
\text { Concepts }\end{array}$ & $\begin{array}{l}\text { Exploring } \\
\text { 3D } \\
\text { Shapes }\end{array}$ & $\begin{array}{l}\text { Module } 2 \\
\text { Section } 3\end{array}$ & $\begin{array}{l}\text { - Collecting } 2 \text { D objects } \\
\text { - Sorting the shapes } \\
\text { - Naming of these shapes } \\
\text { - Real-life applications of } \\
\text { these shapes } \\
\text { - Identifying and counting } \\
\text { vertices, edges and faces. } \\
\text { - Construct and fill table for } \\
\text { faces, vertices, edges } \\
\text { - Make nets }\end{array}$ & $\begin{array}{l}\text { Consolidation of } \\
\text { distinguishing } \\
\text { features of 2D and } \\
\text { 3D shapes. } \\
\text { Increased skills in } \\
\text { use of practical } \\
\text { activities to } \\
\text { investigate and show } \\
\text { relationships } \\
\text { between 2D and 3D }\end{array}$ \\
\hline
\end{tabular}

In this model lecturers have used the selected TESSA resources in a variety of ways: teachers carry out the TESSA activities in schools and report back at the next tutorial or support session; as well, the resources are used in micro-teaching sessions, in face-to-face lectures, and in tutorials.

Examples of this use can be seen on distance education programmes at Egerton University (Kenya), Makerere University and Kyambogo University (Uganda), and the University of Zambia. Course structures here involve punctuation of distance study with relatively long intense face-to-face sessions (typically during the school holidays) and relatively low student numbers. Students are given copies of the individual TESSA study units or are expected to source their own copies from the TESSA web site or from their own institution. Some institutions are beginning to distribute CD-ROMs of the TESSA materials to students. In a variation on this model, colleagues at the Open University of Tanzania are constructing a new diploma course for teachers by drawing heavily on the TESSA materials, which can be seen as a bridge to the more highly structured model.

In the guided use model no pre-selection of TESSA materials is undertaken by university academics; teachers on various courses select (from the TESSA web site) the most appropriate study units for their own needs, devising their own learning pathway through the material. At Our Lady of Apostles Training College (OLA) in Cape Coast, Ghana (working with the University of Cape Coast), the student timetable has been amended and all students have one session per week in the computer labs to browse and study the TESSA materials, choosing activities and resources to use in their assignments, in on-campus micro teaching, and in teaching practice in local schools. Students are also encouraged to contribute to the TESSA forums; the TESSA web site includes a number of forums (online discussion areas). All visitors to the web site can read 
messages in the discussion areas but users are required to register in order to post a contribution. A valid email address is required for registration. The implementation of this session at OLA forced students to create email addresses and become familiar with the use of the web.

At the University of Winneba (Ghana) students have formed a TESSA club. They meet weekly in the university campus to discuss TESSA materials and their experiences of using them. Similarly students on B.Ed. courses at the University of Pretoria (South Africa) are required to select TESSA materials to use during their teaching practice and to discuss their experiences during group reflections and in an individual survey at the end of the practicum. Key to the use of this model is access to the TESSA web site by individual teachers; however, experiences at OLA in Ghana have shown that teachers do not need their own individual Internet-enabled devices to become part of the TESSA community because access to shared institutional computers during short but regular timetabled sessions has been effective in introducing teachers to the TESSA materials.

It is becoming clear that a variety of interacting factors are important in determining how OERs are most easily utilised in open and distance education programmes. More detailed reflection below on the TESSA journey at the University of Fort Hare illustrates some of these factors.

\section{TESSA at the University of Fort Hare, South Africa}

Fort Hare provides one model of what I believe all the universities responsible for teacher education and training should aspire to. (Moon, 2008, p. 5)

Historically, education in South Africa was central to successive apartheid governments' efforts to segregate racial groups and maintain white minority rule. The new democratic government, elected in 1994, was faced with the task of both rebuilding the system and redressing past inequalities. What followed was a plethora of education policies and a consequent dramatic change to both the systemic administration and implementation of education (Lawrence et al., 2006).

Yet although the national Department of Education designed objectives to rectify the imbalances, and they continue to be at the fore, the apartheid legacy remains: "Most currently serving educators received their education and entered teaching when education was an integral part of the Apartheid project" (Department of Education, 2006, p. 6). Since 1994, education in South Africa has followed the top-down approach; numerous policy changes have been conceptualised, planned, and initiated at both national and provincial government levels. Such changes, including the shift to Outcomes Based Education (OBE), have been implemented in very tight timelines and, many commentators argue, with inadequate preparation and resourcing. This poses daunting challenges to both teachers and teacher educators (OECD, 2008).

It is against this context that the University of Fort Hare (UFH) Faculty of Education is tasked with teacher education and development. The university serves an education system that seeks 
radically new curricular and pedagogic practices but that works within structures characterised by poor education quality, teachers with poor subject knowledge, a lack of physical resources in schools, poor support for pupils at home, and meagre teacher support (Department of Education, 2006; Newman, 2008; Department of Education, 2008; Moon, 2008; Pandor, speech, March 12, 2009).

Recognising the need for new forms of teacher education and development resources and keen to harness the potential of ICT platforms ${ }^{1}$, UFH Faculty of Education became involved with the TESSA initiative from the offset. Much initial involvement in the research, design, and development of TESSA study units was at an individual level, and little information was disseminated to the Faculty. Subsequently, recognising the need for institutional coordination, a dedicated TESSA coordinator was established in the Faculty. This enabled deeper awareness of the TESSA OER development process, and, as a result, a number of academics participated in testing the TESSA web site (navigation and user-friendliness) and coordinated their students, particularly teachers studying part-time, in TESSA study unit development testing in their classrooms. A quarterly newsletter of TESSA OER development progress was distributed to all faculty, staff, and students (www.tessafrica.net). This involvement of academics and students in the development stages of TESSA contributed greatly to the subsequent integration of TESSA OERs.

Following the completion of the South African version of the TESSA OERs at the end of 2007, the UFH and the Open University (UK) co-facilitated a workshop at which academics reviewed modules/programmes and mapped these to the TESSA OERs. A mixture of highly structured, loosely structured, and guided use models of integrating TESSA OERs emerged. Not all colleagues were enthusiastic about the potential of TESSA OERs in their curriculum, citing lack of relevance of the materials and satisfaction with existing provision as reasons for their lack of interest. Such attitudes are not unexpected:

Changing a curriculum is always a difficult and problematic project - one likely to arouse conflict, passion, anxiety and resistance. And this is likely to be the case even where there appear to be overwhelming practical reasons for doing so. Morrow (2003, p. 4)

In early 2008, the South Africa version of the TESSA OERs was copied onto the UFH server, greatly enhancing their accessibility. This was an important step; Internet connectivity at the time was highly sporadic, particularly during the period of electricity outages instigated by the national electricity provider. Since the end of 2008, this situation, and Internet bandwidth at the institution, has greatly improved.

\footnotetext{
${ }^{1}$ UFH Faculty of Education's involvement in the DEEP Project exposed the possibilities and potential of ICT in teacher education, even in a province starved of access and connectivity (Leach, 2005)
} 
The flexibility of the TESSA OERs has meant that at UFH the depth and breadth of integration has been determined in response to local context, academic autonomy, and budgetary constraints. As a result, a combination of the forms and modes of use of TESSA OERs has emerged.

\section{Highly Structured: Recognition of Prior Learning (RPL)}

TESSA OERs are used as part of the recognition of prior learning (RPL) process undertaken by teachers applying to enter the part-time Bachelor of Education programme. Assignments towards the development of their RPL portfolio include, amongst others, adapting TESSA resources to the national curriculum statements, preparing lessons using TESSA activities, delivering the lesson, and then engaging in reflection of the teaching and learning episode. The academic responsible for the RPL process explains that one advantage of TESSA OERs is the integration of the subject content and its presentation in a way that is accessible to many teachers who find it difficult to interpret and select subject knowledge at the appropriate level from text books. The RPL process team also placed a printed version of all the TESSA materials in the library, "in case teachers were not comfortable with using computers."

\section{Loosely Structured: Teaching and Learning}

Rationales for integrating TESSA OERs into academic colleagues' teaching included exposing students to local examples of case studies and resources, which many text books in use do not provide, and emphasising activities that focus on classroom practice. One academic offered this reflection:

I particularly like the open-ended nature of the activities, and the way everyday materials are used to introduce and embed scientific vocabulary and concepts. Also, most of the activities require the students to get off of their bums. In order to participate, they have to do things, find things, talk about things, and even dance, yes, dance. (Shaw, 2008, p. 2)

\section{Loosely Structured: Assessment}

Lack of adaptation of assessment approaches and criteria in curriculum innovation projects can often hinder successful adoption and embedding of the innovation. At UFH, TESSA OERs have begun to be used in formal assessment, thus ensuring a synergy between teachers' own learning experiences and those suggested in the TESSA approach for classroom use with pupils. In the UFH in-service programmes students were asked to assess a particular TESSA case study, map the TESSA activity to the national curriculum statement for that learning area (in this case science), and determine learning outcomes and assessment standards suitable for a particular grade of learners. As the academic involved in writing the assessment states, "I always aim for the assessment to be a useful learning experience as well." 


\section{Guided Use: Learning Guides}

Learning guides are module specific learning facilitation tools that serve as maps for students on various programmes and contain organisational as well as learning facilitation components. Academics have included TESSA OERs as a source of reference in their module learning guides.

\section{TESSA Dissemination beyond the University of Fort Hare}

Parallel to the process of integrating TESSA resources within UFH, a concerted effort has been made to share TESSA OERs (predominately the CD-ROM version) outside of UFH, in particular with the District Offices of the Provincial Department of Education $\left(\mathrm{DoE}^{2}\right)$ and directly to teachers within schools. This has been a challenging exercise. Projects in the pipeline, including links to TESSA from the DoE website, integration of TESSA OERs into the DOE teacher support materials currently in development, and further planned presentations to DoE District Offices and schools, suggest some level of progress being made. However, the continuous political and administrative change in the DoE means that TESSA awareness and dissemination remains an ongoing task.

Participation in the TESSA consortium, including involvement in the development and integration of TESSA OERs, has afforded UFH academics and students (both pre-service and in-service) and relevant external stakeholders, such as the DoE, access to communities of practice within the institution, across institutions, and across countries and generated a new discourse of finding, adapting, and sharing educational resources. Though more research needs to be done as to how these communities can be supported (Petrides et al., 2006), TESSA has acted as the constant around which these communities of practice have begun to address important social and educational issues (Moon, 2008).

The interactive coordination of TESSA at UFH, involving workshops, presentations, direct, and indirect communication to both internal and external stakeholders, has generated interested users, and what is becoming apparent is the impact this is having on attracting new users, in particular teacher educators from different institutions in South Africa and beyond. We are deeply encouraged by the interest in the TESSA materials from across the continent, in particular from Namibia, Cameroon, Sierra Leone, Mozambique, Togo, and Niger.

\section{Framing Factors and Next Steps}

OERs have the potential to play a pivotal role in democratising access to knowledge in ways that have a special relevance to education systems in developing countries. Recognising the challenges in education, and in particular teacher education, several OER collections and repositories have

\footnotetext{
2 The Eastern Cape Department of Education has 23 education districts. Key district services include advice and coordination on curriculum, education for learners with special needs, and institutional management and governance.
} 
emerged, though very few accounts of how OERs in Africa are being used are yet available (Atkins et al., 2007).

TESSA is a unique African OER initiative, distinguished by its emphasis on and resources devoted to teacher education and by its adaptation of OERs to local contexts and language. We suggest that TESSA OERs offer a considerable contribution towards overcoming the problem of scarce resources in teacher education. Their design as flexible but structured OERs and provision in a variety of formats supports use in teacher education in ways that suit the local context. The design of TESSA has been such that at several levels users (teachers, teacher educators, and academic leaders) are able to participate as collaborators in a network of social relations rather than as solo practitioners; the TESSA forums, workshops, and advisory council meetings provide space for engagement in a network and for conversations with a focus on issues of practice. Communities of practice, at various levels, are beginning to emerge (and continue to evolve), with institutions and individuals contributing more fully to the global arena as producers of knowledge (Smith et al., 2006).

Analysis of the impact of different integration approaches across the member institutions is only at an early stage, but initial analysis of these different forms of integration reinforces our earlier discussion that to fully exploit the potential of OERs they need to be available in a form that is conceptually strong whilst sensitive to local environments to allow for use across different contexts (Wolfenden, 2008). We are beginning to highlight common critical success factors, which frame how the TESSA OERs are being disseminated to colleagues and integrated into teacher education and professional development curriculum:

\section{Access}

Issues of web connectivity, bandwidth, availability of peripherals (such as printers), and web skills of users are dynamic tensions and vary greatly from locality to locality. Lack of access to new technology tools restricts users' ability to share adaptations and iteratively improve the resources.

\section{Resource}

Whilst OERs are 'free materials' there is a non-trivial cost associated with their use. It has been important not to underestimate the time taken for locating materials, familiarisation, reflection, and in some cases experimentation of how OERs can be integrated into courses and programmes.

\section{Support}

Particularly where the TESSA OERs have been integrated into distance education programmes, support models for the use of OERs may need to change. A recent TESSA project in Nigeria and Sudan pointed to the crucial role of supervisor support for teachers. Project teams concluded that regular monitoring, supervision, and reflective activities were critical to teacher development with the TESSA materials. Provision of such support at a scale within budgetary constraints remains a challenge but we are hopeful 
that the increasing availability of new communication technologies can be harnessed to reduce costs.

\section{Cultural practices}

Institutions' existing practices in terms of the level of direction exercised over curriculum materials and the degree of autonomy of lecturers and students to select material is a crucial factor in the form of integration of the OERs.

\section{Sustainability}

What constitutes as sustainable varies from institution to institution and country to country. A variety of funding models, including sponsorship, government, partnerships, and exchanges, are currently being used (Downes, 2007). However, these are only part of a larger picture, one that includes community and partnerships, co-production and sharing, and distributed management and control. At this stage in the TESSA project, a key challenge is maintaining momentum at the consortium level and sourcing funds to support the maintenance and development of the project infrastructure, in addition to interinstitutional as well as local institutional initiative funding. Central to this is the migration of the key administrative functions from the Open University (UK), which has been leading the project in these first phases, to an African site.

As the TESSA experience is beginning to reveal, the possibilities and potential for harnessing OERs in teacher education are immense and offer an innovative platform to support teacher learning, particularly where local educational resources are scarce. TESSA attempts to bring teacher training nearer to the point of delivery - school classrooms. Cost effective implementation of this approach is possible through the use of a core of highly structured study units adapted for local implementation. Though richer assessment of the impact of TESSA OERs in teacher education is in the pipeline, we suggest that the collaborative design and development and subsequent integration of TESSA OERs is supporting institutions in moving from traditional teacher-led methods of teaching to more democratic, learner-centred models. 


\section{References}

Adekola, O. A. (2007). Language, literacy, and learning in primary schools: Implications for teacher development programs in Nigeria. Washington, DC: World Bank.

Annan, K. (2005). USD200 Million pledged for African universities, including better Internet access. Retrieved March 20, 2009, from http://www.balancingactafrica.com/news/back/balancing-act 274.html

Atkins, D. E., Brown, J. E., \& Hammond, A. L. (2007). A review of the open educational resources (OER) Movement: Achievement, challenges and new opportunities. Report to the William and Flora Hewlett Foundation.

Department of Education (2003). Draft white paper on e-education - transforming learning and teaching through ICT. Pretoria, South Africa.

Department of Education (2005). Educators for the future: Meeting educator shortages to achieve education for all. Pretoria, South Africa.

Department of Education (2006). The national policy framework for educator education and development in South Africa. Pretoria, South Africa.

Department of Education (2006). The national policy framework for teacher education and development in South Africa: 'More teachers better teachers'. Pretoria, South Africa.

Department of Education (2008, November). South Africa: National report on the development of education. Paper presented at the $48^{\text {th }}$ Session of the International Conference on Education, Inclusive Education: The Way of the Future, Geneva.

Department of Education (2009). Education statistics in South Africa 2007. Pretoria, South Africa.

Downes, S. (2007). Models for sustainable open educational resources. Interdisciplinary Journal of Knowledge and Learning Objects, 3, 29-44.

Elmore, R. F. (2000). Building a new structure for school leadership. Washington, DC: Albert Shanker Institute.

Elmore, R. F. (2000a). Getting to scale with good educational practice. In B. Moon, J. Butcher, \& E. Bird (Eds.), Leading professional development in education. London: Routledge Falmer.

Farrell, G., Isaacs, S., \& Trucano, M. (Eds.) (2007). Survey of ICT and education in Africa (Volume 2): 53 Country Reports. Washington, DC: infoDev/World Bank. 
Geser, G. (2007). Open educational practices and resources, OLCOS Roadmap 2012. Open eLearning Content Observatory Services.

Kirk, J., \& Dembélé, M. (2007). More and better teachers needed: Achieving quality education for all. Id21 insights education 6. Retrieved March 20, 2009, from http://www.id21.org/insights/insights-ed06/insights edn 6.pdf

Lawrence, L., \& Moyo, G. (Eds.) (2006). Education and social transformation: An Eastern Cape study. Eastern Cape: University of Fort Hare Press.

Leach, J. (2005). Deep impact: An investigation of the use of information and communication technologies for teacher education in the global south. London: Department for International Development (DFID).

Morrow, S. (2003). Epistemic values in curriculum transformation. In P. Naude \& N. Cloete (Eds.), A tale of three countries: Social sciences curriculum transformations in Southern Africa. Lansdowne: Juta \& Co (Pty) Ltd.

Moon, B. (2007). Research analysis: Attracting, developing and retaining effective teachers: A global overview of current policies and practices. UNESCO. Retrieved March 18, 2009, from http://unesdoc.unesco.org/images/0015/001516/151685E.pdf

Moon, B., \& Wolfenden, F. (2007, November). Open educational resources, international cooperation and teacher education in sub-Saharan Africa. Paper presented at the EADTU Conference, Lisbon, Portugal.

Moon, B. (2008, November). Rethinking the role of the university in teacher education: The teacher education in sub-Saharan Africa (TESSA) experience. Paper presented at the $A C U$ Conference of Executive Heads, Hyderabad, India.

OECD (2007). Giving knowledge for free. The emergence of open educational resources. Paris: OECD Publishing.

OECD (2008). Review of national policies for education: South Africa. Paris: OECD Publishing.

Newman, L. (2008, October 23). SA educational standard is dismal, The Mercury.

Nelson Mandela Foundation (2005). Emerging voices: A Report on education in South African rural communities. Cape Town: HSRC Press.

Pandor, N. (2009). Address by the Minister of Education at the Eastern Cape Provincial Education Summit, Education Leadership Institute, East London, 12-13 March. Retrieved March 20, 2009, from http://www.education.gov.za/dynamic/dynamic $\cdot$ aspx?pageid=306\&id=8415 
Petrides, L., \& Jimes, C. (2006) Open educational resources: Towards a new educational paradigm. iJournal, 14(4).

Schwille J., Dembélé, M., \& Schubert, J. (2007). Global perspectives on teacher learning; improving policy and practice. Paris: UNESCO.

Schwille, J. (2007). Effective professional development for teachers. id21 communicating development research. Retrieved March 20, 2009, from http://www.id21.org/id21ext/insightsed6art1.html

Shaw, P. (2008). Using TESSA science materials, UFH TESSA Newsletter, 2(1).

Smith, M.S., \& Casserly, C.M. (2006). The promise of open educational resources. Change $38(5), 8-17$.

Teffera, D., \& Skauge, T. (n.d.). Teacher education in Africa: An international reference handbook. Project Prospectus.

UNESCO (2006). Teacher supply and demand in sub-Saharan Africa. UNESCO Institute of Statistics. $\quad$ Retrieved $\quad$ March 17, 2009, from http://www.uis.unesco.org/TEMPLATE/pdf/Teachers2006/Regional_Profiles/RegProfile _sub-SahAfrica.pdf

UNESCO (2007). Strong foundations: Early childhood care and education. Paris. Retrieved March 18, 2009, from http://www.unesco.org/education/GMR/2007

UNECSO (2008). Education for all by 2015: Will we make it? Paris. Retrieved March 18, 2009, from http://www.unesco.org/education/gmr2008

Weber, E. (2007). Globalisation, "glocal” development, and teachers' work: A research agenda. Review of Educational Research, 77(3), 279-301.

Wolfenden, F. (2008) The TESSA OER experience: Building sustainable models of production and user implementation. Journal of Interactive Media in Education. Retrieved March 18, 2009, from http://jime.open.ac.uk/2008/03/

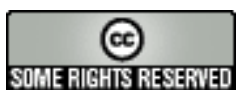

